\title{
Legene og legemiddelindustrien
}

GlaxoSmithKline (GSK) godtok i november 2011 et forlik med den amerikanske regjeringen på 3 milliarder dollar (18 milliarder kroner) for ulovlig markedsføring av en rekke medisiner, inkludert Avandia (1). Denne saken likner mye på tilsvarende bøtelegging (0,5-3 milliarder dollar) av Pfizer, Lilly, Novartis, Merck og AstraZeneca de siste par år i USA (2). Hva er det som foregår, og hvorfor godtar verdens største legemiddelfirmaer slike gigantbøter?

Det dreier seg vesentlig om ulovlig markedsføring og manipulasjon av forskningsdata. Legemiddelfirmaene har, i likhet med alle andre firmaer, som hovedmål å tjene penger. Det er et opplagt og i seg selv aktverdig formål. Men når dette målet går på bekostning av hensynet til pasienten, blir det tvilsomt.

Ta for eksempel Avandias skjebne. Avandia tilhører legemiddelgruppen glitazoner, som minsket insulinresistensen og som i dyreforsøk hadde gunstige virkningen på hjertet. Midlet virket meget lovende. Det ble en stor salgssuksess, særlig i USA (årlig salg over 2 milliarder dollar), og det ble registrert i Norge i 2003. Midlet ble godkjent fordi det reduserte blodglukosenivået hos pasienter med type 2-diabetes, selv om reduksjonen ikke var særlig stor. Det ble ikke forsøkt å påvise virkning på ev. senkomplikasjoner (hjerte, øyne, nerver), men man var optimistisk fordi legemidlet teoretisk kunne være gunstig for hjertet.

Derfor ble det stort oppstyr da Nissen publiserte data fra Food and Drug Administration (FDA) som tydet på at Avandia tvert imot ga økt forekomst av hjerteinfarkt (3). Dette har vært meget kontroversielle data, og diskusjonen har bølget frem og tilbake (4). Problemet er at det ikke finnes studier som primært er designet med tilstrekkelig utsagnskraft (power) til å avgjøre spørsmålet om hvorvidt medikamentet gir økt tendens til hjerteinfarkt. Derimot er det klart at Avandia gir mer hjertesvikt og brudd, og midlet ble avregistrert av European Medicines Agency (EMA) i 2010. FDA har innsnevret bruken betydelig (5).

Legemiddelmyndighetene har lært en lekse: Surrogatendepunkter er utilstrekkelig. Det må harde endepunkter (død, hjerteinfarkt, kreft) til for å få registrert nye legemidler til behandling av f.eks. diabetes, det er ikke nok med effekt på blodsukker- eller kolesterolnivå. Dette gjør det mye mer krevende, kostbart og risikofylt for legemiddelfirmaene å få registrert nye midler. Bruken av generiske preparater har økt betydelig, noe som gjør at firmaenes fortjeneste er sterkt avtakende. Legemiddelfirmaene står overfor betydelig utfordringer i denne situasjonen. Hvordan reagerer de?

På tre forskjellige måter - delvis avhengig av firma. Noen reduserer sine forskningsavdelinger og satser mer på markedsføring (6). Da Pfizer kunngjorde en slik strategi, steg etter hvert aksjekursen med $20 \%$. Andre satser på nærmere samarbeid med universiteter og oppstartsfirmaer med gode legemiddelideer. Enkelte firmaer har derimot økt forskningsinnsatsen, det gjelder f.eks. Merck (MSD).

Det er et paradoks at samtidig som vi står midt oppe i en revolusjon i vår forståelse av biologi og sykdom, har legemiddelindustrien (big pharma) vansker med å finne nye, gode legemidler. De mest spennende nye midler i dag er kanskje antistoffbaserte og opprinnelig utviklet av mindre firmaer med sterk vektlegging av forskning.
Må vi i fremtiden tenke oss andre måter å skaffe sikker kunnskap på enn randomiserte, dobbeltblinde studier? Kanskje må offentlige myndigheter inn og designe og finansiere legemiddelstudier i samarbeid med industrien. Det kan tenkes at man kan bruke populasjonsbaserte studier med kontrollpersoner fra naboområder osv. Det er viktig å tenke nytt. Uansett blir det ekstremt viktig med løpende overvåking av nye legemidler som kommer på markedet.

Legemiddelfirmaene på sin side må finne en ny forretningsmodell som krever mindre overskudd for at de skal kunne drive rasjonelt. Vi ser at i Norge reduserer firmaene staben, kanskje særlig i de medisinske avdelingene, mens de forsøker å opprettholde den rene markedsføringsaktiviteten.

Markedsføring som er blitt funnet kriminell av det amerikanske rettsapparatet, er svært ofte gjort i samarbeid med leger. Legene har store fordeler av å samarbeide med legemiddelindustrien. Våre store internasjonale møter ville bli helt annerledes uten utstillingene derfra. Et nytt arbeid viser at hele $71 \%$ av legene som satt $i$ «guideline panels» hadde interessekonflikter (7). Vi er kyniske når det

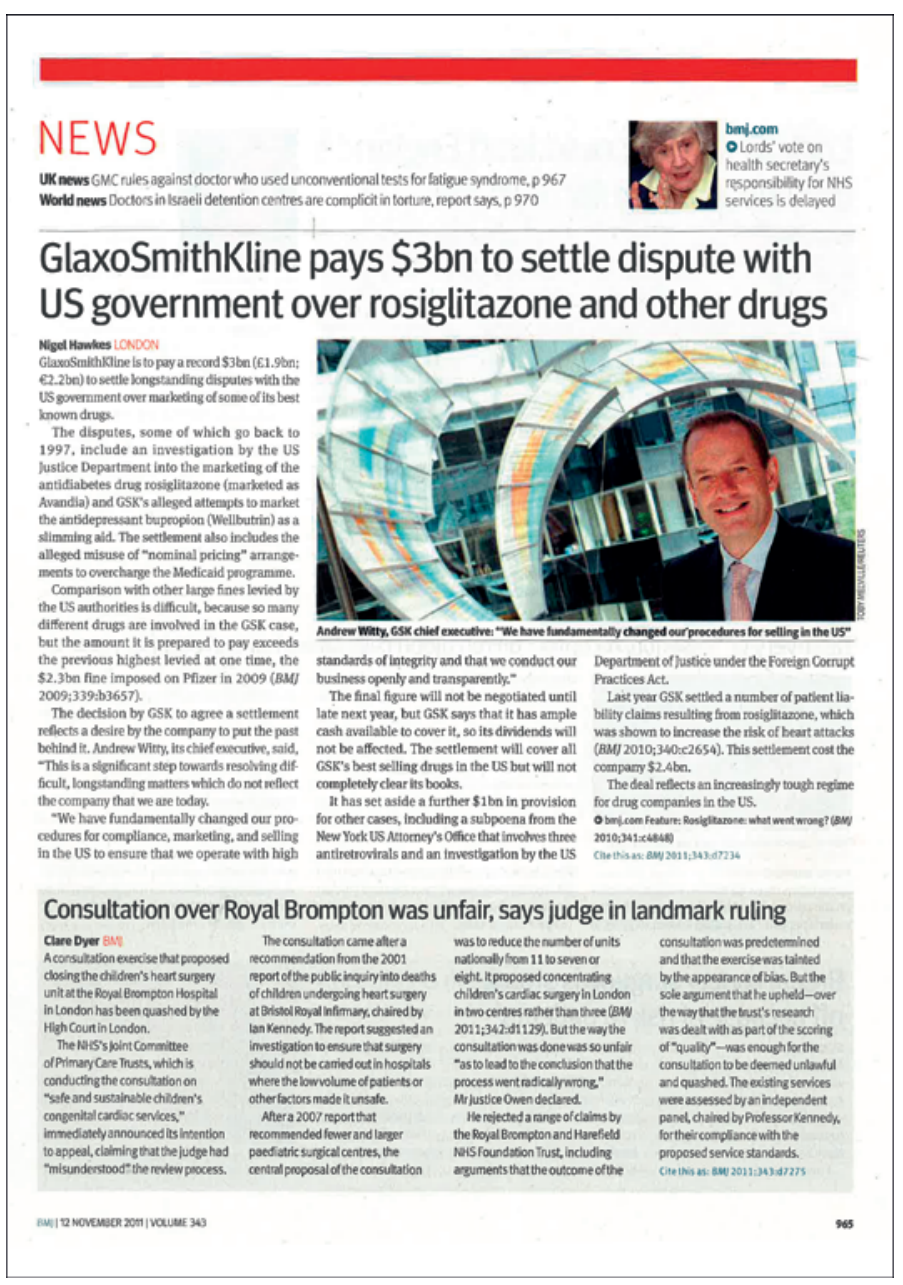

Faksimile av BMJs omtale av forliket mellom GlaxoSmithKline og den amerikanske regjeringen (9) 
passer oss og naive når det passer. Men mye tyder på at vi vil få en forandring til det bedre. F.eks. var tidsskriftet som du leste for fem år siden utenkelig i sin daværende form uten annonser fra legemiddelindustrien. Nå utgjør fra legemiddelannonsene bare $13 \%$ av budsjettet. I tillegg har f.eks. Harvard University nylig kommet med mye strengere regler for samarbeidet mellom legemiddelindustrien og legene (8), regler som legene delvis stritter imot.

Det begynner med oss selv. Det må bli uakseptabelt å tjene to herrer. Vi skal selvfølgelig samarbeide med industrien, men dette må være transparent og i overensstemmelse med samfunnets interesser. Som Edwin Gale nylig fremhevet i en leder i BMJ: Lovgivning vil ikke forandre situasjonen, for gode investorer vil alltid være et skritt foran. Det må en kulturendring til. Først når legene endrer holdning, vil vi få den legemiddelindustrien vi fortjener (7).

\section{Kristian F. Hanssen}

k.f.hanssen@medisin.uio.no

Kristian F. Hanssen (f. 1942) er overlege dr.med. ved Endokrinologisk avdeling, Oslo universitetssykehus, professor II ved Universitetet i Oslo og daglig leder for Oslo Diabetesforskningssenter. Han har fått den store europeiske forskningsprisen for senkomplikasjonsforskning (Pedroli/ Golgi Prize).

Oppgitte interessekonflikter: Hanssen har mottatt forelesningshonorar fra Novo Nordisk, Lilly, Aventis, Pfizer og BMS og har sittet i rådgivningsgruppe for Avandia. Han har de siste årene latt honorarene gå direkte inn i forskningsbudsjettene.

\section{Litteratur}

1. Glaxo settles cases with U.S. for \$ 3 billion. New York Times 3.11.2011

2. Merck to pay $\$ 950$ million in Vioxx settlement. Wall Street Journal 23.11.2011.

3. Nissen SE Wolski K. Effect of rosiglitazone on the risk of myocardial infarction and death from cardiovascular causes. N Engl J Med 2007; 356: 2457-71.

4. Hanssen KF. Antidiabetikum med økt risiko for karsykdom. Tidsskr Nor Lægeforen 2007; 127: 2972.

5. Woodcock J, Sharfstein JM, Hamburg M. Regulatory action on rosiglitazone by the U.S. Food and Drug Administration. N Engl J Med 2010; 363: 1489-91.

6. New chief revises goals and spending for Pfizer. New York Times 1.2.2011.

7. Gale EA. Conflicts of interest in guideline panel members. BMJ 2011; 343: d5728.

8. Wilson D. Harvard teaching hospitals cap outside pay. New York Times 2.1.2010.

9. Hawkes N. GlaxoSmithKline pays $\$ 3$ bn to settle dispute over rosiglitazone and other drugs. BMJ 2011; 343: d7234. 